\title{
Epidemiology of central nervous system mycoses
}

\author{
Arunaloke Chakrabarti \\ Department of Medical Microbiology, Postgraduate Institute of Medical Education and Research, Chandigarh - 160 012, India
}

Fungal infections of the central nervous system (CNS) were considered rare until the 1970s. This is no longer true in recent years due to widespread use of corticosteroids, cytotoxic drugs and antibiotics. Immunocompromised patients with underlying malignancy, organ transplantations and acquired immune deficiency syndrome are all candidates for acquiring fungal infections either in meninges or brain. A considerable number of cases of CNS fungal infections even in immunocompetent hosts have been reported. A vast array of fungi may cause infection in the CNS, but barring a few, most of them are anecdotal case reports. Cryptococcus neoformans, Candida albicans, Coccidioides immitis. Histoplasma capsulatum are common causes of fungal meningitis; Aspergillus spp., Candida spp., Zygomycetes and some of the melanized fungi are known to cause mass lesions in brain. Few fungi like C. neoformans, Cladophialophora bantiana, Exophiala dermatitidis, Ramichloridium mackenzie, Ochroconis gallopava are considered as true neurotropic fungi. Most of the fungi causing CNS infection are saprobes with worldwide distribution; a few are geographically restricted like Coccidioides immitis. The infections reach the CNS either by the hematogenous route or by direct extension from colonized sinuses or ear canal or by direct inoculation during neurosurgical procedures.

Key words: Aspergillus, Candida, central nervous system, Cryptococcus, epidemiology, fungi, melanized fungi, mycoses

Fungal infection of the central nervous system (CNS) is a life-threatening disease. A variety of fungi cause infection of CNS - either an acute or chronic meningitis or space-occupying lesion [Table 1]. Acute or neutrophilic meningitis is most commonly seen in Candida meningitis, while Cryptococcus neoformans classically cause chronic lymphocytic meningitis and Coccidioides immitis cause granulomatous meningitis. Though meningitis is the most common presentation

\begin{tabular}{ll}
\hline \multicolumn{2}{c}{ Table 1: Fungi causing central } \\
\hline Meningitis & Space-occupying lesions \\
Common agents & Aspergillus spp. \\
Cryptococcus neoformans & Zygomycetes \\
Coccidioides immitis & Candida spp. \\
Candida albicans & Melanized fungi \\
Histoplasma capsulatum & Histoplasma capsulatum \\
Uncommon or rare agents & Coccidioides immitis \\
Blastomyces dermatitidis & Pseudallescheria boydii \\
Paracoccidioides brasiliensis & Fusarium spp. \\
Melanized fungi & Blastomyces dermatitidis \\
Aspergillus spp. & Sporothrix schenckii \\
Zygomycetes & Paracoccidioides brasiliensis \\
Sporothrix schenckii & Pencillium spp. \\
& Ustilgo spp. \\
& \\
Very rare agents & Trichosporon spp. \\
Rhodotorula rubra & Trichoderma longibrachiatum \\
Blastoschizomyces capitatus & Chaetomium strumarium \\
& Chaetomium atrobrunneum \\
& Schizophyllum commune \\
& Paecilomyces spp. \\
& Metarrhizium anisopliae \\
& Microascus cinereus \\
& Curvularia clavata \\
& Ramichloridium obovoideum \\
& Trichophyton spp. \\
& Acrophialophora fusispora \\
\hline
\end{tabular}

of CNS mycoses, some of the filamentous fungi cause brain abscess or granuloma more commonly than meningitis. The increased occurrence of CNS mycoses is parallel to the increasing number and the diversity of fungal infections of other sites ${ }^{[1-7]}$ A similar increase in frequency of CNS mycoses is reflected in multiple series from India as well. ${ }^{[7-14]}$

The CNS is protected by a mechanical barrier from colonization or invasion of fungi. However, in suitable conditions fungi can reach the CNS by a hematogenous route or when the anatomic barrier is breached by trauma, surgery or by direct extension from paranasal sinus or ear canal. 


\section{Predisposing Factors}

Predisposing factors in fungal meningitis vary with individual fungal pathogen [Table 2]. The development of fungal meningitis requires both exposure to offending pathogen and often some deficiency of host defenses that permit the fungus to access and replicate in the meninges. Pathogenic fungi Coccidioides immitis, Histoplasma capsulatum and even Cryptococcus neoformans may affect immunocompetent hosts but may occur more often in those with depressed cellmediated immunity, such as AIDS. C. neoformans most strongly characterizes this group. ${ }^{[13,14]}$ Uncommon agents like melanized fungi rarely cause meningitis in immunocompetent hosts.

The mass lesion of brain due to fungi occurs by either direct extension or hematogenous spread. Direct extension occurs commonly from colonized paranasal sinuses or ear canal. The lesion is increasingly being reported over the last two decades and is attributable to an increasing number of immunocompromised patients who are surviving longer periods because of advances in medical management, a larger aging population, increased number of malignancies and transplant recipients. ${ }^{[15-17]}$ Recipients of hematopoietic stem cell transplants (HSCTs) were far more likely to have fungal brain abscess (5.2\%) than solid organ transplant recipients $(0.4 \%)(\mathrm{P}<0.001) \cdot{ }^{[15]}$ Infection is also facilitated by exposure to dank environments, rotting vegetable material or nearby construction, all of which fill the air with infectious conidia or spores. Colonization with these fungal propagules must occur many times daily, but development of disease usually occurs in the host with impaired polymorphonuclear leukocyte and macrophage function. In those patients who develop cerebral mass lesions, infections appear to be more frequent by colonization and then invasion of paranasal sinuses rather than by metastasis from a remote lung lesion or percutaneous inoculation. ${ }^{[12,17-21]}$ In India, Sudan, Saudi Arabia, such cases were reported in many immunocompetent hosts. With the increase of diabetic patients worldwide, uncontrolled diabetes or diabetic ketoacidosis is an important predisposing factor for CNS mycoses. ${ }^{[22,23]}$

\section{Causative Fungi}

A few fungi were considered as neurotropic as they tend to localize in the CNS after invading the human body [Table 3]. However, most cases of CNS mycoses are part of dissemination due to candidiasis, aspergillosis or zygomycosis. Until recently, Candida species have been considered a very common cause of fungal meningitis and brain abscess. A postmortem survey of 1,752 consecutive complete autopsies done at the University of Kentucky Medical Centre from 1964 through 1973 revealed that candidiasis was the most common (43\%) fungal infection in the brain even in the endemic fungal area. ${ }^{[24]}$ Over the years, the spectrum of fungal agents causing CNS mycoses has changed [Table 4]. Aspergillus spp. is the most common agent in intracerebral granuloma or abscess ${ }^{[7,12,17]}$ and $C$. neoformans is the most common agent causing fungal meningitis, especially in the AIDS era. ${ }^{[13,14,25]}$ The ecology and distribution of some of the causative fungi is elaborated further.

\section{Cryptococcus neoformans}

C. neoformans has two varieties: var. neoformans (Serotype A and D), var. gattii (Serotype B and C). Serotype $A$ is ubiquitous and associated with bird droppings and Serotype D is found in Europe with heterogeneous distribution. ${ }^{[26]} \mathrm{B}$ serotype had initially been found in the vicinity of Eucalyptus trees ( $E$. camaldulensis, E. teriticornis) in Australia, California and elsewhere. ${ }^{[27-29]}$ Since 1993, the Serotype B has been isolated occasionally in India from patients with chronic meningitis though Serotype A is the common isolate ${ }^{[14,30]}$ and the agent was isolated from E. camaldulensis trees of

\section{Table 3: Neurotropic fungi}

True

Relatively common to affect central nervous system

Cryptococus neoformnas Cladophialophora bantiana Exophiala dermatitidis

Ramichloridum mackenziei Ochroconis gallopova
Coccidiodes immitis Chaetomium atrobrunneum Chaetomium strumarium Bipolaris hawaiiensis Bipolaris spicifera Curvularia pallescens

\section{Predisposing factors}

Hematological malignancy

Solid tumors

Transplantation

Acquired immunodeficiency syndrome

Steroids

Trauma/burns

Antibiotics

Catheter (intravenous/urinary)
Table 2: Predisposing factors in fungal meningitis

$\begin{array}{cc}\text { Cryptococcus } & \text { Coccidioides } \\ ++ & + \\ + & \pm \\ ++ & + \\ +++ & + \\ ++ & + \\ - & - \\ - & - \\ - & -\end{array}$

\section{Histoplasma}

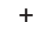

$\pm$

$+$

$++$

$++$

$-$

$-$ 


\begin{tabular}{|c|c|c|c|c|}
\hline Series & Parker et al. 1978 ${ }^{[1]}$ & Sharma et al. 1997[12] & Dubey et al, 2005 $5^{[17]}$ & Sundaram et al, $2006^{[7]}$ \\
\hline Years of study & $\begin{array}{c}1964-1976 \\
{\left[13 y^{*}\right]}\end{array}$ & $\begin{array}{c}1980-93 \\
{[14 \mathrm{v}]}\end{array}$ & $\begin{array}{c}1980-2003 \\
{[23 y]}\end{array}$ & 1988-2004 \\
\hline No. of cases & 39 & 95 & 40 & 130 \\
\hline $\begin{array}{l}\text { Causative fungi } \\
\text { Candida spp. }\end{array}$ & $19(49)^{* *}$ & $11(12)$ & $1(3)$ & $5(4)$ \\
\hline C. neoformans & $9(23)$ & $12(13)$ & $3(7)$ & $2(2)$ \\
\hline Aspergillus spp. & $2(5)$ & $66(69)$ & 25(63) & $73(56)$ \\
\hline Zygomycetes & $5(13)$ & NK & 7 (18) & $40(30)$ \\
\hline H. capsulatum & $2(5)$ & NK & - & - \\
\hline B. dermatitidis & $1(3)$ & NK & - & - \\
\hline Melanized fungi & $1(3)$ & NK & $4(10)$ & $3(2)$ \\
\hline Others & - & $6(6)$ & - & $7(6)$ \\
\hline
\end{tabular}

NK - not known; *y=years; **Figures in parenthesis indicate percentage

north India. ${ }^{[31]}$ However, in recent years 22 tree species belonging to diverse genera and families have so far been reported to harbor one or both varieties. Decayed wood in trunk hollows of Syzygium cumini (Indian blackberry) was shown as the main well-documented primary environmental niche of both varieties in northwestern India. ${ }^{[32,33]}$ The ecological niche of Serotype C is unknown. Though C. neoformans has been isolated from several environmental sources, there has been no outbreak attributable to the environment.

C. neoformans var. neoformans is the commonest cause of chronic fungal meningitis and $90 \%$ of these infections occur in immunocompromised hosts. ${ }^{[34]}$ The majority of AIDS isolates are var. neoformans, even in areas where var. gattii is endemic. Despite having a high exposure rate to all hosts, C. neoformans var. neoformans is considered an opportunistic pathogen because it predominantly affects immunocompromised hosts. In contrast, var. gattii has a limited geographical distribution and affects predominantly immunocompetent male hosts in their second decade of life. There is no report of animal to human transmission and human to human transmission is rare.

The overall incidence of cryptococcosis is not known. However, it is higher among patients with AIDS in Southeast Asia and Africa than in the United States. The disease appears to be less frequent in Europe. ${ }^{[35]}$ A population-based active surveillance for cryptococcosis in Houston, Atlanta, San Francisco and Alabama in USA from 1992 to 1994 found the majority of patients to be male, consistent with demographics of HIV infection and $89 \%$ of patients had CD4 counts $<100$ cells $/ \mu \mathrm{L}$. The analysis of all four areas found decreased incidence of cryptococcosis in Atlanta and San Francisco from 1992 to 1994 , which was attributed to the increased use of azoles. ${ }^{[36]}$ In the developed world, the introduction of potent antiretroviral therapies resulted in a decrease in the incidence of cryptococcosis associated with AIDS.

Brain mass lesions or cryptococcoma due to C. neoformans are much less common than meningitis for Serotypes A and D. On the contrary, Serotype B, frequent in non-immunocompromised patients, often produces a pseudotumor mass in the brain. Occasionally, a mass lesion may be present without meningitis. ${ }^{[37]}$

\section{Candida spp.}

Candida species are commensal of the skin and mucous membrane. Among Candida spp., C. albicans is the most common agent causing meningitis and brain abscess. Other species, such as C. tropicalis, C. parapsilosis, C. krusei, C. Iusitaniae or C. glabrata are less common pathogens. Meningitis is more frequent in infants than in older patients. Rarely, Candida meningitis may occur in an otherwise healthy person. ${ }^{[38]}$ Autopsies of patients who died with disseminated candidiasis showed a high frequency of brain abscesses (in up to $50 \%$ of cases)..$^{[2,6]}$

The development of meningitis or mass lesion in the brain due to Candida spp. depends on factors controlling local proliferation and the access of Candida to the CNS. The predisposing factors listed in Table 2, favor the overgrowth of Candida and then dissemination or direct inoculation to the CNS. One example is pregnancy, when Candida vaginal populations flourish. When a mother with dense candidal vaginal overgrowth delivers a premature infant, especially with defects in neural tube, such as meningomyelocele, rapid infection of the meninges may result. ${ }^{[19]}$ In newborns, CNS candidiasis is a disease of the premature or compromised infant. ${ }^{[2]}$ Candida meningitis related to neurosurgery was also reported..$^{[39,40]}$ In a series of 18 patients, direct inoculation into the CNS during surgery by way of an infected wound or ventriculostomy occurred in $72 \%$ patients. The time between insertion of ventriculostomy devices and infection was 13 to 36 days. $^{[39]}$ In another series of 21 patients, $86 \%$ had ventricular shunt. ${ }^{[40]}$

\section{Aspergillus spp.}

Aspergillus spp., ubiquitous organisms in soil and decaying vegetation, enter the body by way of the respiratory tract including the paranasal sinuses. ${ }^{[41]}$ Invasion of the CNS occurs either by direct extension 
from an area anatomically adjacent to the brain or by the hematogenous route. Besides primary focus in the lung, hematogenous dissemination has also originated from direct bloodstream inoculation in illicit-drug user ${ }^{[42]}$ or as a consequence of open-heart surgery. ${ }^{[43]}$ Direct extension of the brain may occur from the external ear, nose, paranasal sinuses, eye and following head injury or via the spinal canal secondary to lumbar puncture or following intracranial surgery. Intrauterine Aspergillus infection with the spread of the disease to CNS of infant may also occur. ${ }^{[2,44,45]}$

Aspergillus fumigatus is the most prevalent species followed by A. flavus and A. terreus. However, A. flavus is the commonest agent when the disease is extended from paranasal sinuses to CNS, especially in countries like India, Sudan, Pakistan, Saudi Arabia. ${ }^{[20,21,44,45]}$ Isolated meningitis in aspergillosis is rare. Brain abscesses are frequent in disseminated invasive aspergillosis. ${ }^{[6]}$ Bone marrow transplant patients, particularly allogenic transplant with graft versus host disease treated with large dose of steroids or who have CMV infection, represent a major risk of CNS aspergillosis. ${ }^{[46,47]}$ Prolonged severe neutropenia and high-dose corticosteroids are the major predisposing factors in cancer and solid organtransplant patients. ${ }^{[6,46]}$ However, the disease may occur even in an apparently immunocompetent host. ${ }^{[3,7,12,17]}$

\section{Zygomycetes}

CNS zygomycosis is due to species under the Genera Rhizopus, Rhizomucor, Absidia, Mucor, Cunninghamella, Apophysomyces and Saksenaea. Environmental reservoirs and the mechanism of transmission of these agents is similar to the Aspergillus spp. ${ }^{[48]}$ Zygomycetes rely on a preconditioned host. These fungi thrive in a highly acid environment, which is rich in carbohydrate. Thus a diabetic patient with ketoacidosis has a double threat of defective phagocyte function (from acidosis) and provides an environment for rapid invasion. ${ }^{[22]}$ Zygomycetes also proliferate in a neutropenic host and in patients where serum iron concentration is raised by deferoxamine. ${ }^{[49,50]}$ Intravenous drug addicts can also infect themselves with contaminated material and a brain abscess will develop. ${ }^{[1,52]}$ A skin portal of entry has also been described, particularly associated with elasticized surgical bandages. ${ }^{[52]}$ Absidia corymbifera was isolated in one case after a penetrating head injury. ${ }^{[53]}$ A few patients may develop zygomycosis without underlying immune defect. ${ }^{[22,52]}$ Isolated cerebral zygomycosis has also been described. ${ }^{[54]}$

\section{Dimorphic fungi}

Of all dimorphic fungi Coccidioides immitis and Histoplasma capsulatum are the common agents causing CNS infections. C. immitis, a common cause of meningitis, is environmentally restricted in Southwest
United States, Guatemala, Honduras, Nicaragua, Argentina, Paraguay and Venezuela. ${ }^{[6,55,56]}$ Coccidioidal meningitis occurs in one-third to half of patients with disseminated disease. The disease may occur in an immunocompetent host. The patients usually have meningitis within a few months of their primary pulmonary infection. In HIV positive patients of Arizona $11-27 \%$ had coccidioidal meningitis. ${ }^{[55,56]}$ Patients with solid organ transplant, treated with corticosteroids and pregnant women are at higher risk of dissemination after primary infection. ${ }^{[6]} \mathrm{C}$. immitis is a rare cause of brain abscess. Miliary granulomas have been reported. ${ }^{[57]}$ The disease can be the result of a primary infection, a re-infection or a reactivation after a previous primary infection. ${ }^{[55]}$

Histoplasmosis caused by Histoplasma capsulatum is endemic in the Ohio River and Mississippi river valleys in North America, Mexico, Argentina, Brazil, Colombia, Venezuela, other tropical countries in Southeast Asia and sub-Saharan Africa. The fungus is found in soil enriched with bird droppings or guano of bats, particularly in caves. Outbreaks may occur in highly endemic areas. ${ }^{[6,58]}$ $\mathrm{H}$. capsulatum may cause meningitis in $5-25 \%$ of its victims who have AIDS. This is similar to estimates in non-AIDS patients with disseminated disease. ${ }^{[58,59]}$ Primary infection, re-infection or reactivation of a previous contamination can occur. Besides HIV infection, CNS histoplasmosis may occur in patients undergoing solid organ transplantation or patients treated with conrticosteroids. ${ }^{[58]}$ Histoplasmosis will develop as a result of reactivation of a latent infection in less than 1\% of patients with AIDS in non-endemic areas. ${ }^{[58]}$ Central nervous system histoplasmosis was observed in 10$20 \%$ of all disseminated cases. ${ }^{[58,59]}$ Brain abscesses are infrequent, present as miliary non-caseating granulomas, sometimes with a larger size called histoplasmoma. ${ }^{[60]}$

In blastomycosis, CNS localization may occur in 5\% of immunocompetent persons and $40 \%$ of the patients with advanced HIV infection. Meninges are rare locations. Brain abscesses are also uncommon with half of them being solitary lesions. ${ }^{[61,62]}$ In paracoccidioidomycosis, penicilliosis due to Penicillium marneffei and sporotrichosis CNS infections are very rare.

\section{Melanized fungi}

CNS infections by melanized fungi have increasingly been reported in recent years..$^{[9,63,64]}$ Primary cerebral infections are predominantly caused by Exophiala dermatitidis, Cladophialophora bantiana, Ramichloridium mackenzie under the order Chaetothyriales. Occasionally, Ochroconis gallopava is encountered. Secondary cerebral infections are usually an extension from chronic sinusitis and are due to grass-inhabiting species under the Genera Bipolaris, Dissitimurus, Exserohilum (order Pleosporales). 
Exophiala dermatitidis is the main neurotropic agent of East Asia although it is found worldwide as saprobes. Since CNS infection is found exclusively in Asian patients, the possibility of race-dependent virulence has been suggested. ${ }^{[63]}$ The agent seems to affect an apparently immunocompetent young population. ${ }^{[65]}$ In the US a pseudo-epidemic involving five (four CNS infections) cases as a result of contaminated injected steroid solution has been reported. ${ }^{[66]}$

Cladophialophora bantiana, a neurotropic fungus, has rarely been isolated from sources other than living mammal tissue. Central nervous system infection due to $C$. bantiana is reported worldwide, though a general preference for warmer climate with high humidity is apparent. ${ }^{[63,64]}$ Cases from arid climatic zones are rare. The infection is often found in immunocompetent young males. Around $40 \%$ of the infections are reported in solid organ transplant recipients, intravenous drug abusers or those on steroid therapy. ${ }^{[64,67-69]}$

CNS infection due to Ramichloridium mackenzie is found in patients living in or originating from the Middle East although the fungus has never been isolated from the environment or air of the same region. Still, restriction of human infections to the Middle East suggests a preference of the saprobic phase. Most of the patients had a history of previous major surgery. Otherwise, often the patients were immunocompetent. ${ }^{[64,70,71]}$

The agents causing secondary cerebral infection include Bipolaris spicifera, Curvularia lunata, Cladosporium cladosporioides, Nodulisporium species etc. The infection is encountered in apparently immunocompetent hosts with chronic sinusitis and the agents are commonly airborne saprobes. ${ }^{[64]}$

\section{Other fungi}

Scedosporium apiospermum, a saprobe isolated worldwide from soil, manure, sewage, polluted water has emerged among the newly recognized pathogens of CNS. ${ }^{[2,73]}$ It has the same epidemiology as Aspergillus spp. and has been found to cause pneumopathy in near-drowning people, because it is present in large numbers in polluted water. In some cases the fungus can even disseminate hematogenously to the CNS of neardrowning victims, causing abscesses in the brain. ${ }^{[73]}$ The victims were little children and young adults with the mean age of 23.8 years. The ratio of males to females was $12: 5{ }^{[73]}$ which is in concordance with higher prevalence of drowning in males. Direct inoculation of pathogen through orbital trauma or lumbar puncture can also be a factor for CNS infection. ${ }^{[74}$

A limited number of brain abscesses due to Fusarium species has been reported. Fusarium spp. are common in soil and are plant pathogens. Disease can be seen in severely immunocompromised hosts. ${ }^{[75]}$ There are a number of anecdotal case reports of CNS fungal infections due to a variety of rare species [Table 1].

\section{Conclusion}

Fungal infections of the central nervous system are increasingly being recognized all over the world. The infection is generally seen in immunocompromised patients but some fungi are known to affect the apparently immunocompetent host. Though the involvement of the central nervous system in most cases occurs as a part of disseminated infection, few fungi are predominantly neurotropic. An increased awareness among physicians and a high level of suspicion help in establishing the diagnosis. Yeasts predominantly cause meningitis and mycelial fungi cause mass lesion of brain. Other than fungi causing endemic mycoses, these fungi are prevalent worldwide and are found as saprobes in the environment.

\section{References}

1. Parker JC Jr; McCloskey JJ, Lee RS. The emergence of candidosis: The dominant postmortem cerebral mycosis. Am J Clin Pathol 1978;70:316

Salaki JS, Louria DB, Chmel H. Fungal and yeast infections of central nervous system: A clinical review. Medicine 1984;63:108-32.

3. Kim DG, Hong SC, Kin HJ, Chi JG, Han MH, Choi KL, et al. Cerebral aspergillosis in immunologically competent patients. Surg Neurol 1993;40:326-31

4. Jellinger KA, Setinek U, Drlicek M, Bohm G, Steurer A, Lintner F. Neuropathology and general autopsy findings in AIDS during the last 15 years. Acta Neuropathol 2000;100:213-20.

Baddley JW, Salzman D, Pappas PG. Fungal brain abscess in transplant recipients: Epidemiologic, microbiologic and clinical features. Clin Transplant 2002;16:419-24.

6. Dupont B. Fungal infections of the central nervous system. In: Anaissie EJ, McGinnis MR, Pfaller MA, editors. Clinical Mycology. $1^{\text {st }}$ ed. Churchill Livingstone: New York; 2003. p. 539-53.

7. Sundaram C, Umabala P, Laxmi V, Purohit AK, Prasad VS, Panigrahi M, et al. Pathology of fungal infections of the central nervous system: 17 years experience from southern India. Histopathology 2006;49:396-405.

8. Banerjee AK, Singh MS, Kak VK, Talwar P, Rout D. Cerebral aspergillosis: Report of 8 cases. Indian J Pathol Microbiol 1977;20:91-9.

9. Chandramuki A, Ramadevi MG, Shankar SK. Cerebral cladosporiosis: A neuropathological and microbiological study. Clin Neurol Neurosurg $1983 ; 85: 245-53$

10. Anandi V, Ajay K, John J. Central nervous system fungal infections: A review of 6 years experience at Vellore. In: Abraham J, editor. Progress in clinical Neurosciences, Vol. 8. Guardian Press: Madras, India; 1993 p. $36-46$

11. Khanna N, Chandramuki A, Desai A, Ravi V. Cryptococcal infections of the central nervous system: An analysis of predisposing factors, laboratory findings and outcome in patients from south India with special reference to HIV infection. J Med Microbiol 1996;45:376-9.

12. Sharma BS, Khosla VK, Kak VK, Banerjee AK, Vasishtha RK, Prasad KS, et al. Intracranial fungal granuloma. Surg Neurol 1997;45:48997.

13. Chakrabarti A, Sharma A, Sood A, Grover R, Sakhuja V, Prabhakar S, et al. Changing scenario of cryptococcosis in a tertiary care hospital in north India. Indian J Med Res 2000;112:56-60.

14. Banerjee U, Datta K, Majumdar T, Gupta K. Cryptococcosis in India: The awakening of a giant? Med Mycol 2001;39:51-67.

15. Singh N, Husain S. Infections of the central nervous system in transplant recipients. Transpl Infect Dis 2001;2:101-11.

16. Baddley JW, Salzman D, Pappas PG. Fungal brain abscess in transplant recipients: Epidemiologic microbiologic and clinical features. Clin Transplant 2002;16:419-24. 
17. Dubey A, Patwardhan RV, Sampath S, Santosh V, Kolluri S, Nanda A. Intracranial fungal granuloma: Analysis of 40 patients and review of the literature. Surg Neurol 2005;63:254-60.

18. Chakrabarti A, Sharma SC, Chander J. Epidemiology and pathogenesis of paranasal sinus mycoses. Otolaryngol Head Neck Surg 1992;107:74550 .

19. Graybill JR. Mycoses causing mass lesions of the central nervous system. In: Kibbler CC, Mackenzie DW, Odds FC, editors. Principles and practice of clinical Mycology. John Wiley and Sons: New York; 1996. p. 95-102.

20. Chakrabarti A, Sharma SC. Paranasal sinus mycoses. Indian J Chest Dis Allied Sci 2000;42:293-304.

21. Murthy JM, Sundaram C, Prasad VS, Purohit AK, Rammurti S, Laxmi V. Sinocranial aspergillosis: A form of central nervous system aspergillosis in south India. Mycoses 2001;44:141-5.

22. Chakrabarti A, Das A, Mandal J, Shivaprakash MR, George VK, Tarai B, et al. The rising trend of invasive zygomycosis in patients with uncontrolled diabetes mellitus. Med Mycol 2006;44:335-42.

23. Pellacchia V, Terenzi V, Moricca LM, Buonaccorsi S, Indrizzi E, Fini G. Brain abscess mycotic and bacterial infection in a diabetic patient: Clinical report and review of literature. J Craniofac Surg 2006;17:578-84.

24. Parker JC Jr, McCloskey JJ, Solanki KV, Goodman NL. Candidosis: The most common postmortem cerebral mycosis in an endemic fungal area. Surg Neurol 1976;6:123-8.

25. Mitchell TG, Perfect JR. Cryptococcosis in the era of AIDS-100 years after the discovery of Cryptococcus neoformans. Clin Microbiol Rev 1995;8:515-48

26. Dromer F, Gueho E, Ronin O, Dupont B. Serotyping of Cryptococcus neoformans by using a monoclonal antibody specific for capsular polysaccharide. J Clin Microbiol 1993;31:359-63.

27. Ellis DH, Pfeiffer T.J. Natural habitat of Cryptococcus neoformans var. gattii. J Clin Microbiol 1990;28:1642-4.

28. Pfeiffer T, Ellis D. Environmental isolation of Cryptococcus neoformans from California. J Infect Dis 1991;163:929-30.

29. Pfeiffer TJ, Ellis DH. Environmental isolation of Cryptococcus neoformans var. gattii from Eucalyptus tereticornis. J Med Vet Mycol 1992;30:407-8.

30. Padhye AA, Chakrabarti A, Chander J, Kaufman L. Cryptococcus neoformans var. gattii in India. J Med Vet Mycol 1993;31:165-8.

31. Chakrabarti A, Jatana M, Kumar P, Chatha L, Kaushal A, Padhye AA. Isolation of Cryptococcus neoformans var. gattii from Eucalyptus camaldulensis in India. J Clin Microbiol 1997;35:3340-2.

32. Randhawa HS, Kowshik T, Khan ZU. Decayed wood of Syzygi um cumini and Ficus religi osa living trees in Delhi/New Delhi metropolitan area as natural habitat of Cryptococcus neoformans. Med Mycol 2003;41:199209.

33. Randhawa HS, Kowshik T, Preeti Sinha K, Chowdhury A, Khan ZU, Yan Z, et al. Distribution of Cryptococcus gattii and Cryptococcus neoformans in decayed wood of Syzygi um cumini trees in north-western India. Med Mycol 2006;44:623-30.

34. Speed B, Dunt D. Clinical and host differences between infections with the two varieties of Cryptococcus neoformans. Clin Infect Dis 1995;21:28-36.

35. Levitz SM. The ecology of Cryptococcus neoformans and the epidemiology of Cryptococcosis. Rev Infect Dis 1991;13:1163-9.

36. Hajjeh RA, Conn LA, Stephens DS, Baughman W, Hamill R, Graviss E, et al. Cryptococcosis: Population-based multistate active surveillance and risk factors in human immunodeficiency virus-infected persons. Cryptococcal Active Surveillance Group. J Infect Dis 1999;179:44954.

37. Lewis JL, Robinocich S. The wide spectrum of cryptococcal infections. Am J Med 1972;53:315-22.

38. Chattopadhyay B. Candida tropicalis meningitis: A case report. J Laryngol Otol 1981;95:1149-51.

39. Nguyen MH, Yu VL. Meningitis caused by Candi da species: An emerging problem in neurosurgical patients. Clin Infect Dis 1995;21:323-7.

40. Geers TA, Gordon SM. Clinical significance of Candida species isolated from cerebrospinal fluid following neurosurgery. Clin Infect Dis $1999 ; 28: 1139-47$
41. Mohandas S, Ahuja GK, Sood VP, Virmani V. Aspergillosis of the central nervous system. J Neurol Sci 1978;38:229-33.

42. Kaufman DM, Thal LJ, Farmer PM. Central nervous system aspergillosis in two young adults. Neurology 1976;26:484-8.

43. Newman WH, Cordell AR. Aspergillus endocarditis after open heart surgery: Report of a case and review of literature. J Thorac Cardivasc Surg 1964;48:652-60.

44. Milosev B, el-Mahgoub S, Aal OA, el-Hassan AM. Primary aspergilloma of paranasal sinuses in the Sudan: A review of seventeen cases. Br J Surg 1969;56:132-7.

45. Veress B, Malik OA, el-Tayeb AA, el-Daoud S, Mahgoub ES, el-Hassan AM. Further observations on the primary paranasal Aspergillus granuloma in Sudan: A morphological study of 46 cases. Am J Trop Med Hyg 1973;22:765-72.

46. Ribaud P, Chastang C, Latge JP, Baffroy-Lafitte L, Paraquet N, Devergie A, et al. Survival and prognostic factors of invasive aspergillosis after allogenic bone marrow transplantation. Clin Infect Dis 1999;28:322-30.

47. Lin SJ, Schranz J, Tentsch SM. Aspergillosis case fatality rate: Systemic review of literature. Clin Infect Dis 2001;32:358-66.

48. Sugar AM. Mucormyeosis. Clin Infect Dis 1992;14:S126-9

49. Boelaert JR, van Roost GF, Vergauwe PL, Verbank J.J, deVroev C, Sequert MF. The role of desferrioxamine in dialysis associated mucormycosis: Report of three cases and review of literature. Clin Nephrol 1988;29:261-6.

50. Pagano L, Ricei P, Tonso A, Nosari A, Cudillo L, Montillo M, et al. Mucormycosis in patients with hematological malignancies: A retrospective clinical study of 37 cases. Br J Hematol 1997;99:331-6.

51. Hopkins RJ, Rothman M, Fiore A, Goldblum SE. Central mucormycosis associated with intravenous drug use: Three case reports and review. Clin Infect Dis 1994;19:1133-7.

52. Ribes JA, Vanover-Sams CL, Baker D.J. Zygomycetes in human disease. Clin Microbiol Rev 2000;13:236-301.

53. Mackenzie DW, Soothill JF, Millar JH. Meningitis caused by Absidia corymbifera. J Infect 1988;17:241-8.

54. Verma A, Brozman B, Petito CK. Isolated cerebral mucormycosis: Report of a case and review of literature. J Neurol Sci 2006;240:65-9.

55. Bronnimann DA, Adam RD, Galgiani JN, Habib MP, Peterson EA, Porter $\mathrm{B}$, et al. Cocidioidomycosis in the acquired immunodeficiency syndrome. Ann Intern Med 1987;106:372-9.

56. Fish DG, Ampel NM, Galgiani JN, Dols CL, Kelly PL, Johnson CH, et al. Coccidioidomycosis during human immunodeficiency virus infection: A review of 77 patients. Medicine 1990;69:384-91.

57. Mendel E, Milefchik EN, Ahmado J, Gruen P. Coccidioidomycosis brain abscess. Case report. J Neurosurg 1994;81:614-6.

58. Wheat LJ, Batteiger BE, Sathapatayavongs B. H istoplasma capsulatum infections of central nervous system. Medicine 1990;69:244-60

59. Wheat LJ, Slama TG, Zeekal MI. Histoplasmosis in the acquired immune deficiency syndrome. Am J Med 1985;78:203-10.

60. Venger BH, Landon G, Rose JE. Solitary histoplasmoma of the thalamus: Case report and literature review. Neurosurgery 1987;20:784-7.

61. Roos KL, Bryan JP, Maggio WW, Jane JA, Scheld WM. Intracranial blastomycoma. Medicine 1987;66:224-35

62. Pappas PG, Pottage JC, Powderly WG, Fraser VJ, Stratton CW McKenzie S, et al. Blastomycosis in patients with acquired immuno deficiency syndrome. Ann Intern Med 1992;116:847-53.

63. Horre R, de Hoog GS. Primary cerebral infections by melanized fungi: A review. Stud Mycol 1999;43:176-93.

64. Kantarcioglu AS, de Hoog GS. Infections of the central nervous system by melanized fungi: A review of cases presented between 1999 and 2004 Mycoses 2004;47:4-13

65. Chang CL, Kim DS, Park DJ, Kim H., Lee CH, Shin JH. Acute cerebral phaeohyphomycosis due to Wangiella dermatitidis accompanied by cerebrospinal fluid eosinophilia. J Clin Microbiol 2000;38:1965-6.

66. Centers for Disease Control and Prevention (CDC). Exophiala infection from contaminated injectable steroids prepared by a compounding pharmacy - United States, July-November 2002. MMWR Morb Mortal Wkly Rep 2002;51:1109-12.

67. Slama AD, Rogers T, Lord GM, Leschler RI, Mason PD. Multiple Cladosporium brain abscesses in a renal transplant patient. Transplantation 
1997;63:160-2.

68. Walz R, Bianchin M, Chaves M, Cerski MR, Severo LC, Londero AT. Cerebral phaeohyphomycosis caused by Cladophialophora bantiana in a Brasilian drug abuser. J Med Vet Mycol 1997;35:427-31.

69. Delfino D, De Hoog S, Polonelli L, Benecchi M, Fanti F, Gelatioto S, et al. Survival of a neglected case of brain abscess caused by Cladophialophora bantiana. Med Mycol 2006;44:651-4.

70. Kanj SS, Amr SS, Roberts GD. Ramichloridi um makenzi ebrain abscess: Report of two cases and review of literature. Med Mycol 2001;39:97102.

71. Ravankar SG, Sutton DA, Rinaldi MG. Primary central nervous system phaeohyphomycosis: A review of 101 cases. Clin Infect Dis 2004;38:20616 .

72. Acharya A, Ghimire A, Khanal B, Bhattacharya S, Kumari N, Kanungo R. Brain abscess due to Scedosporium apiospermum in nonimmunocompromized child. Indian J Med Microbiol 2006;24:231-2.
73. Buzina W, Feierl G, Haas D, Reinthaler FF, Holl A, Kleinert R, et al. Lethal brain abscess due to the fungus Scedosporium apiospermum (telemorph Pseudallescheria boydii ) after a near drowning incident: Case report and review of the literature. Med Mycol 2006;44:473-7.

74. Nesky MA, McDougal EC, Peacock JE Jr. Pseudallescheria boydii brain abscess successfully treated with voriconazole and surgical drainage: Case report and literature review of central nervous system pseudallescheriasis. Clin Infect Dis 2000;31:673-7.

75. Guarro J, Gene J. Opportunistic fusarial infections in humans. Eur J Clin Microbiol Infect Dis 1995;14:741-54.

Accepted on 31-01-2007

Source of Support: Nil, Conflict of Interest: None declared.

\section{Author Help: Online Submission of the Manuscripts}

Articles can be submitted online from http://w w w.journalonw eb.com. For online submission articles should be prepared in two files (first page file and article file). Images should be submitted separately.

1) First Page File:

Prepare the title page, covering letter, acknowledgement, etc., using a word processor program. All information which can reveal your identity should be here. Use text/rtf/doc/pdf files. Do not zip the files.

2) Article file:

The main text of the article, beginning from Abstract till References (including tables) should be in this file. Do not include any information (such as acknowledgement, your names in page headers, etc.) in this file. Use text/rtf/doc/pdf files. Do not zip the files. Limit the file size to $400 \mathrm{~kb}$. Do not incorporate images in the file. If file size is large, graphs can be submitted as images separately without incorporating them in the article file to reduce the size of the file.

3) Images:

Submit good quality colour images. Each image should be less than $\mathbf{4 0 0} \mathbf{~ k b}$ in size. Size of the image can be reduced by decreasing the actual height and width of the images (keep up to about 4 inches) or by reducing the quality of image. All image formats (jpeg, tiff, gif, bmp, png, eps, etc.) are acceptable; jpeg is most suitable. The image quality should be good enough to judge the scientific value of the image. Always retain a good quality, high resolution image for print purpose. This high resolution image should be sent to the editorial office at the time of sending a revised article.

4) Legends:

Legends for the figures/images should be included at the end of the article file. 